\title{
Blasts Increased by Greater than or Equal to 50 Percent
}

National Cancer Institute

\section{Source}

National Cancer Institute. Blasts Increased by Greater than or Equal to 50 Percent. NCI

Thesaurus. Code C153121.

A semi-quantitative microscopic finding indicating that the amount of immature

mononuclear cells in a sample from a certain subject has increased by at least 50 percent over a prior sample from the same subject. 